\title{
VIAJE A ÍTACA. EL CASO DE LAS ADAPTACIONES AL CINE ESPAÑOL DE DOS NIVOLAS DE UNAMUNO
}

\author{
Asier ARANZUBÍA COB, Imanol ZUMALDE ARREGUI \\ y Santos ZUNZUNEGUI DÍEZ \\ Universidad Carlos III de Madrid y Universidad del País Vasco \\ aaranzub@hum.uc3m.es; imanol.zumalde@ehu.es; \\ santos.zunzunegui@ehu.es
}

Resumen: Una vez constatada la esterilidad del eterno debate a propósito de la fidelidad, en este trabajo se pretende defender el análisis de casos concretos como única vía productiva de acercamiento a los problemas suscitados por las relaciones entre literatura y cine.

Abstract: After stating the futility of the everlasting debate regarding fidelity, this paper aim is to defend the analysis of specific cases as the sole productive way of approaching the obstacles concerning the relantionship among literature and film.

Palabras clave: Adaptación. Fidelidad. Unamuno. Nivola. Cine Español.

Key Words: Screen version. Fidelity. Unamuno. Nivola. Spanish Cinema. 


\section{A VUELTAS CON LA FIDELIDAD}

Uno de los temas que más tinta ha hecho correr en el ámbito de la denominada literatura cinematográfica es, como permite comprobar cualquier rápida consulta de las bases bibliográficas al uso, el de las denominadas «adaptaciones literarias». De entrada, conviene advertir de lo impropio de tal denominación que, generalmente, suele utilizarse para dar cobertura a un conjunto heterogéneo de películas, cuyo origen, más o menos remoto, suele ser una obra literaria preexistente, aunque la relación que media entre el hipertexto (el filme) y el hipotexto (la obra literaria) puede ser lo suficientemente variable como para esconder una casuística interminable.

Pero si la apelación es impropia, lo es por razones más sólidas. Una de las primeras que puede aducirse es que semejante denominación peca por defecto, toda vez que una película puede tener su origen más o menos lejano no solo en obras literarias, sino también en obras musicales, pictóricas o escultóricas que proporcionan la base de la que parte la denominada «adaptación». No cabe duda de que en alguno de estos terrenos la base literaria puede ser importante, como es el caso de la ópera, en la que el libreto dramático ofrece un material similar al que puede facilitar una obra teatral, pero en otros las cosas son más complejas como testimonia el caso de las obras musicales llevadas a la pantalla. Para ilustrar este fenómeno haremos referencia únicamente a dos filmes lo suficientemente diferentes entre sí: el primero, la famosa obra de Walt Disney Fantasía (1940) en la que una serie de temas musicales célebres (Bach, Beethoven, Dukas, Tchaikovsky, etc.) son «ilustrados» (entrecomillamos a propósito la palabra) mediante una variada tipología de dibujos animados; el segundo, menos conocido, el cortometraje de Jean-Marie Straub y Danièle Huillet Einleitung zu Arnold Schoenbergs «Begleitmusik zu einer Lichtspielszene» (1972), que utiliza como detonante una partitura del músico germano, compuesta en $1929 / 30^{1}$, para ponerle imágenes. La película se compone de la lectura en un estudio de grabación de diversas cartas de Schoenberg a Kandinsky, a propósito del antisemitismo de este último, enmarcadas entre la presentación del trabajo de Schoenberg que lleva a cabo el propio Straub y la enunciación por Danièle Huillet de un breve texto de Brecht, en el que el dramaturgo señala que decir la verdad sobre el fascismo es hablar contra el capitalismo, de una serie de imágenes documentales de bombardeos americanos en Vietnam que son acompañadas de

${ }^{1}$ La «Música de acompañamiento para una escena de película», refleja musicalmente el espíritu del cine mudo. 
las célebres fotos de los comuneros de 1871 fusilados en sus ataúdes que se exhiben en el Museo Carnavalet de París, así como de la filmación de dos noticias periodísticas (una en italiano y otra en alemán), en las que se informa de la absolución de los ingenieros constructores de los crematorios de Auschwitz. Todo ello ritmado por bloques de fotogramas negros que pautan la aparición de las diversas imágenes. De esta forma los cineastas «ponen en imágenes» una partitura musical pre-existente, procediendo a la búsqueda de imágenes que se hagan cargo, actualizándolos, de los contenidos sociopolíticos que se encuentran (¿latentes, implícitos?; conviene advertir que en la partitura se anotaba «Amenaza, Peligro, Miedo, Catástrofe») en la obra de Schoenberg.

De idéntica forma, nada impide que una película crezca sobre el humus que le ofrezca una escultura o un cuadro. Podríamos incluir en este apartado trabajos tan notables como los llevados a cabo por Luciano Emmer a finales de los años treinta del pasado siglo al «narrativizar» mediante el montaje, en una serie de películas pioneras, la obra pictórica de Giotto, Carpaccio o El Bosco (Bazin, 1996: 268-273). En este sentido no viene mal recordar que no estamos haciendo referencia a la práctica, cultivada lo mismo por un cierto cine primitivo que por determinado cine moderno, del tableau vivant, cuya utilización remite, de manera fundamental, al nivel plástico y no tanto al narrativo que es el que ahora nos interesa de manera prioritaria.

\subsection{La adaptación en el marco de una teoría de la traducción}

Por eso, antes de insistir en esta dirección conviene retornar al campo más reducido de las «adaptaciones literarias». Para subrayar varias cosas que, muchas veces, suelen dejarse de lado en provecho de sesudas (e inútiles) disquisiciones acerca de la mayor o menor fidelidad de la obra cinematográfica en relación con la literaria que le sirve de base. En primer lugar, hay que tener presente que cualquier adaptación debe incluirse en el marco teórico general que le proporciona una teoría de la traducción (Steiner, 1995). En este sentido conviene recordar que Jakobson, tomando como punto de partida la idea de Peirce de que la significación de cualquier signo no es sino su traducción a otro más accesible en el cual se desarrolla más a fondo, propone un esquema triádico que nos puede ser de utilidad. Dice Jakobson (1959) que puede clasificarse la traducción de los signos verbales en tres grandes categorías. Propondrá la denominación de reformulación cuando se traduzca una ocurrencia verbal mediante otros signos verbales de la misma lengua. Es- 
tamos en el territorio de la paráfrasis. Existirá traducción propiamente dicha cuando los signos de una lengua sean interpretados mediante signos provenientes de otra lengua natural. Finalmente, hablaremos de transmutación para definir un fenómeno claramente intersemiótico, que recubre todos aquellos casos en los que los signos verbales son interpretados mediante otros sistemas de signos no verbales: gestuales, matemáticos, icónico-auditivos, etc.

Conviene no perder de vista, por tanto, que cualquier «transmutación» de un texto literario en forma de filme supone la modificación, la alteración del objeto que se toma como punto de partida. No solo porque el texto de partida es «traducido», «corporeizado», «concretizado», sino porque, además, ningún texto literario será ya nunca el mismo tras su adaptación. Baste pensar en las reverberaciones que determinadas adaptaciones han tenido sobre las obras de las que parten, no solo insuflándoles, a veces, una segunda vida editorial, sino haciéndonos ver las obras concernidas bajo una luz nueva que las ilumina para siempre y las tiñe con colores que nos hacen pensar en esas obras a través del filtro que nos ofrece su encarnación cinematográfica.

«Adaptación» que puede verse como un trayecto (conocido, precisamente, con ese nombre) que lleva desde un punto de partida (el texto literario) a uno de llegada (el filme), pasando por un estado intermedio al que muy pocas veces se le concede la importancia que merece: el guión, a veces denominado literario. Este último se configura como una huella del texto original y posee un estatuto ambiguo bien resaltado por Pier Paolo Pasolini (1966: 76-83) cuando hablaba del guión (para el que el autor italiano acuñó la denominación de «esceno-texto») como de una «estructura que tiende hacia otra estructura», «una forma que tiende hacia otra forma». Por tanto, nos encontramos ante una pura «estructura de transición», que aún conserva identidades materiales notables con el material de partida (se trata de un texto escrito, literario por tanto), aunque puede complementarse con elementos de visualización (por ejemplo, un story-board) que apuntan hacia el estadio final aún por llegar. Como Pasolini vio con gran claridad, el guión es una estructura de apoyo destinada a abolirse en provecho del filme terminado, sin que esto tenga nada que ver con su mayor o menor calidad literaria, ni con el hecho de que, en ciertos casos, los guiones puedan conocer una vida editorial independiente tanto del texto original (cuando exista) como del filme al que sirven de soporte ${ }^{2}$.

${ }^{2}$ Llegados a este punto conviene recordar una distinción que suele dejarse de lado demasiado a menudo y que puede dar origen lamentables confusiones. La palabra castellana «guión» suele ser utilizada a 
Conviene tener en cuenta que este «viaje» puede serlo de ida y vuelta. Desde los comienzos mismos del cine se conoce el fenómeno de las «novelizaciones» que no consiste sino en la «transmutación» de un filme en forma posterior de relato literario. Nada se opone, por tanto, a que una adaptación dé nacimiento no solo a un filme, sino que, en el mismo impulso, sirva de pivote a un nuevo texto literario que no se confunda con el original. De la misma manera, una película realizada a partir de un guión «original» (las comillas solo apuntan a que esta dimensión de originalidad es más rara de lo que suele pensarse) puede derivar en el nacimiento de un texto literario que puede vivir su propia vida independiente. Un solo caso: la novelización de La guerra de las galaxias (Star Wars, George Lucas, 1977), aparecida en forma de libro gracias al éxito del filme y, con posterioridad, declinada en forma de saga literaria más o menos independiente de la cinematográfica.

Pero esto no es todo. Porque, de hecho, todo filme está siempre rodeado de «literatura». Aquí entra en juego ese ambiguo campo que suele denominarse «literatura cinematográfica» y que permite a determinados sujetos autocalificarse como «escritores cinematográficos». Como es lógico estamos pensando en el terreno de la crítica cinematográfica que, en el mejor de los casos (James Agee, Guillermo Cabrera Infante, por citar solo a dos notables escritores), recubre experiencias en las que puede hablarse de una verdadera práctica de la escritura a partir del análisis de determinadas películas o cineastas y que en el peor se confunde con la publicidad más o menos encubierta de determinados intereses económicos que subyacen (o están en la superficie misma) del fenómeno cinematográfico.

\subsection{Dos tipos de operaciones: reducir y añadir}

Señalado lo anterior, quedarían por repasar, aunque sea de forma somera, dos problemas interrelacionados. El primero, tiene que ver con una pregunta que pocas veces suele explicitarse y que apunta hacia el corazón de buen número de los malentendidos que suelen encontrase en los interminables debates sobre el tema de las adaptaciones literarias al cine. La pregunta podría

\footnotetext{
veces como equivalente de dos cosas bien distintas y para las que los anglosajones disponen de dos expresiones diferentes. Una cosa es el shooting script, o guión de rodaje y que hace referencia al texto literario - con o sin indicaciones de visualización - que precede al filme, y otra, muy distinta el continuity script o cutting continuity que recoge la descripción más o menos esquemática del contenido de la banda imagen y de la banda sonora del filme terminado. Se trata, por tanto, en este último caso de un texto literario que nace a posteriori de la película. En francés existen las expresiones scénario y découpage après montage para describir estos dos aspectos de la literatura fílmica.
} 
formularse, de forma voluntariamente sencilla, de la siguiente forma: ¿Qué es lo que, en realidad, se adapta cuando se adapta una obra literaria (novela, obra de teatro, poema)? A veces la respuesta adopta las apariencias de una sofisticada distinción que nos lleva de forma indirecta al corazón del asunto. Por ejemplo, cuando se afirma que la diferencia entre un novelista y un guionista reside en que el primero escribe y el segundo trama, narra y describe. Como si en las novelas no existiesen tramas, ni contuvieran descripciones y en ellas no se narrase. En el fondo, lo que hay que entender es que en un guión los ejercicios de estilo están fuera de sitio (o todo lo más confinados a los diálogos, aunque a veces se suele usar como reproche la alusión al carácter demasiado «literario» de los mismos).

Quizás podríamos plantear las cosas con mayor claridad si reconociéramos que lo que se adapta no es el texto literario como tal, sino que del mismo se toma unas veces un esqueleto narrativo, una intriga; otras, una nómina de situaciones y personajes; a menudo ambas cosas a un tiempo y que, las más de las veces, se suele prescindir en la «adaptación» de todo lo que quede al margen de estos aspectos. Bien es verdad que, con frecuencia, una voz en off puede inscribir en la banda sonora una parte literal del texto de la obra de origen y que los diálogos pueden tomarse tal cual de la obra de partida. Pero lo normal es que cuando se piensa en una adaptación se piensa en llevar a cabo sobre el texto de origen una serie de operaciones (reducir, cortar, aligerar y concentrar; pero también añadir, dilatar o complementar), que, sobre todo, afectan a los aspectos arriba aludidos. Comprender este hecho y ponerlo en relación con ese otro al que hemos hecho alusión más arriba (el cambio de materia de expresión involucrada en la «adaptación») deberían bastar para terminar, de una vez por todas, con el debate inacabable e inútil acerca del grado de fidelidad que una película mantiene en relación con la obra literaria que le sirve de base. A diferencia de lo que sucede en el amor, campo en el que la fidelidad es difícil pero posible, en el mundo de las adaptaciones literarias se trata de una verdadera imposibilidad ante la que ceden los impulsos más voluntariosos. Aunque bien es verdad que se nos ocurre una posible fórmula de fidelidad que, salvo prueba en contrario, nunca ha sido ensayada hasta ahora, pero que puede ser descrita de forma tentativa para, de esta forma, completar el abanico de alternativas y volver actual (pese a que sea de manera indirecta) la posibilidad virtual contenida por las posibilidades tecnológicas ofrecidas por lo que antes se conocía con el nombre de «el dispositivo cinematográfico». Conviene precisar que si esto es así se debe al hecho constitutivo de que las obras literarias pertenecen de lleno al campo de lo que Nelson Goodman (1968) llama «artes alográficas» y Gérard 
Genette (1996) «obras de inmanencia ideal, es decir, las consistentes en un tipo común con varios especímenes correctos» ${ }^{3}$. Lo que quiere decir, en otras palabras, que, a diferencia, por ejemplo, de lo que sucede con la pintura, los obras literarias permiten (casi siempre) la distinción entre el «objeto de manifestación» (tal o cual ejemplar de tal o cual edición con su correspondiente paginación y tipografía, propiedades puramente contingentes) y el «objeto de inmanencia» (el texto propiamente dicho, el espacio ideal en donde reside, digamos, su literariedad).

Por eso podemos aceptar que una posible adaptación fiel de un texto literario podría ser la que "pusiera en pantalla», partiendo de un ejemplar cualquiera de cualquiera de las ediciones existentes de una obra determinada, la totalidad de sus páginas. Probemos una descripción sencilla de este filme inexistente: ante los ojos del espectador (¿atónito?, ¿perplejo?) discurrirían debidamente filmadas una a una y en riguroso orden de paginación, todas y cada una de las páginas que conformen el volumen que se «adapte». Las únicas condiciones que la filmación y el montaje deberían respetar son las de que el texto debería de ser perfectamente legible y que la persistencia de cada plano se ajustara a una duración razonable relacionada con el tiempo que un lector medio invertiría en leer la página que tiene antes sus ojos ${ }^{4}$. Para mantener uno de los ejemplos repetidos por Genette, podrían filmarse de esta manera las 117 páginas que ocupa el texto literario (a las que se podrían añadir las 7 del prólogo del propio Unamuno) en la edición que poseemos de La tía Tula (en concreto la de Alianza Editorial, publicada en el año 2002), dando lugar a una adaptación «fiel» de la obra de Unamuno 5 . Sin duda podrá discutirse si estamos ante una «adaptación» o ante una mera «reproducción» de la obra original, pero lo que es innegable es que estaríamos ante una película que consiste en imágenes, en las que se recogen la huella dejada en el ce-

\footnotetext{
${ }^{3}$ En buena medida las reflexiones que siguen se inspiran en Genette (1996).

4 Para no complicar innecesariamente las cosas suponemos que la película carece de sonido y no nos ocupamos del problema del color. También dejamos de lado la posibilidad de que el texto en pantalla recoja sólo los aspectos descriptivos del relato y que los diálogos sean leídos por actores e incorporados en la banda sonora. Se abre aquí un campo fascinante de variaciones conceptuales explorado de forma relativamente sistemática por uno de los filmes esenciales del cine español de los años setenta del pasado siglo: la película de Isidoro Valcárcel Medina, titulada La celosía (1972), que «adapta» la novela de Alain Robbe-Grillet, titulada La jalousie (París: Minuit; versión castellana de Juan Petit, La celosía, Barcelona: Seix-Barral, 1965), publicada originalmente en 1957.

${ }^{5}$ La edición a la que hacemos referencia contiene una introducción a cargo de José-Carlos Mainer, en páginas numeradas de la 7 a la 27 . Sería aún mejor utilizar una que prescindiera de cualquier aparato crítico para dejar a la obra desnuda de cualquier interferencia externa. O considerar la filmación de la introducción como un bonus a la manera de los que suelen incluirse en las ediciones en DVD de las películas.
} 
luloide por las páginas del texto. De forma más exacta: por las páginas de la edición concreta que se ha filmado, de la que las imágenes reproducen todas sus singularidades tipográficas y de paginación que, como es obvio, varían de una edición a otra.

Por tanto, hemos cambiado de materia de expresión, aunque no se haya tocado para nada el «objeto de inmanencia». Señalamos esto último, porque en cualquier adaptación cinematográfica el objeto de inmanencia textual es el texto fílmico y no el texto literario de origen. Podríamos decir que la operación que hemos realizado (siquiera de forma virtual) hace presente en cada copia de la película dos objetos de inmanencia diferentes: el literario, propiamente dicho (La tía Tula de Unamuno) y el cinematográfico. La filmación cinematográfica de La tía Tula, realizada por X (en todas las copias - ¿cuántas? - que se hicieran del filme) remitiría al objeto de inmanencia fílmico y, en el mismo gesto, al objeto de inmanencia literario.

Puede pensarse que este ejercicio, al que nos hemos entregado en los párrafos anteriores, carece de interés y que se parece a esas obras límites que tan de moda estaban acostumbrados a practicar los artistas de vanguardia en la década de los sesenta del pasado siglo. Lo que sería verdad si no fuese porque la emergencia de Internet nos ha familiarizado con este tipo de prácticas: la experiencia implicada en el ejercicio que he propuesto no es muy distinta de lo que surge cuando leemos en pantalla tal o cual texto. Lo que ha sucedido hoy en día es que el avance tecnológico ha vuelto innecesarias determinadas prácticas estéticas de tipo rupturista. Pero qué duda cabe, con todo, que existe una diferencia sustancial entre el tipo de imagen que proporciona la pantalla del ordenador y la que brota de una pantalla blanca en el interior (real o virtual) de una sala oscura. La primera, tiene un mero carácter instrumental, estrictamente reproductivo; la segunda, pertenece, de lleno, al mundo del arte y ahí reside toda su fuerza. Digámoslo una vez más, arte no es más que lo que hace ver y una película del tipo que hemos imaginado tiene al menos la virtud de hacernos ver dónde residen los límites (en el sentido radical de la palabra) de los procesos de adaptación. Solo por eso una película, como la que hemos descrito, merecería ser (o haber sido) realizada. En ningún caso debe menospreciarse «la obra del arte».

\section{ESTUDIO DE CASOS: LAS NIVOLAS DE UNAMUNO}

Una vez constatado (esperamos que definitivamente) el carácter ontológicamente infiel de toda «adaptación» de un texto literario a la pantalla, se 
nos ocurre que la única forma productiva de encarar el manido asunto, del que nos venimos ocupando en estas páginas, pasa, necesariamente, por el análisis de casos concretos y la consiguiente dilucidación del mayor o menor grado de infidelidad de cada una de las adaptaciones. Dicho de otra forma: dado que la tozuda realidad demuestra que no existen sino grados o niveles de infidelidad, podemos considerar la «fidelidad» como un caso específico de infidelidad: aquel que reduce al mínimo esa distorsión consustancial al ejercicio de adaptación de una obra literaria al cine. Siguiendo este orden de cosas, la adaptación «fiel» sería aquella que emprende esas transformaciones inherentes al trasvase de materia de expresión (de la escrita a la audio-visual), atendiendo, cuando los haya, a una suerte de mandatos (algunos explícitos otros muchos implícitos) presentes en la letra del texto de partida y que, de alguna manera, prefiguran ya su concreción audio-visual. Dichos mandatos funcionarían así como una suerte de protocolos de seguridad a través de los cuales los propios textos de origen tratarían de controlar, en la medida de lo posible, el grado de distorsión que inevitablemente habrá de introducir la futura adaptación.

Con objeto de desarrollar estas cuestiones teóricas sobre el terreno práctico de los casos concretos, en los párrafos que siguen centraremos nuestra atención en las adaptaciones de la obra novelística de un autor que ya ha comparecido en estas páginas: Miguel de Unamuno. En concreto, vamos a estudiar las dos adaptaciones más relevantes que el cine español ha acometido hasta la fecha de la obra del escritor vasco ${ }^{6}$ : La tía Tula (Miguel Picazo, 1964) y Abel Sánchez. Historia de una pasión (Carlos Serrano de Osma, 1946). Binomio que nos permitirá observar de cerca dos modelos contrapuestos (a la vez que complementarios) de praxis adaptativa, toda vez que el primero (y más conocido) de ellos ejerce con probidad y criterio de las dos operaciones al uso en estas lides (reducir y añadir), mientras que el segundo se sale de la norma constriñendo a su mínima expresión las extirpaciones y aditamentos consustanciales a todo ejercicio de traducción fílmica de una novela. Veamos cómo se lleva a la práctica una y otra variante de la adaptación.

${ }^{6}$ Conviene recordar que la obra de Unamuno, sobre todo la novelística - o nivolesca-, pero también la dramática, filosófica e incluso poética, posee unas características muy determinadas que nos permiten hablar de una obra homogénea, en la que continuamente se vuelve a los mismos temas, ideas, situaciones, $\mathrm{y}$, en el caso más concreto de la novela, a la misma manera de contar. Una peculiar y esquemática manera de contar que Luciano Gonzalez Egido (Unamuno, 2001: 18) ha descrito en los términos siguientes: «Descalificado el argumento, es decir las peripecias narrativas, después de haber eliminado las descripciones de los personajes, y los paisajes de sus acciones, y después de haber prescindido de las localizaciones geográficas y de las circunstancias temporales, la novela unamuniana queda reducida a la presentación y al desarrollo de los conflictos interiores de sus criaturas de ficción» 


\subsection{La tía Tula (Miguel Picazo, 1964)}

Sin un espacio geográfico ni un tiempo histórico definidos en los que apoyarse, la esquemática trama de La tía Tula discurre sobre un fondo impreciso en el que se reconoce vagamente la España de principios del siglo XX. A falta de mayores precisiones sirven de referencia las pistas que sobre el particular aporta el Prólogo que antecede a la novela fechado «En Salamanca, ciudad, en el día de los Desponsorios de Nuestra Señora del año de gracia milésimo novecentésimo y vigésimo». Aunque el 26 de noviembre de 1920 que este atrio data como fin de una obra que vio la luz definitivamente en 1921 no fue sino el colofón de un proceso creativo ovíparo, como gustaba decir Unamuno, que se prolongó durante, al menos, dos décadas.

En sus comentarios introductorios a la edición de la novela de Unamuno (2002: 8), José-Carlos Mainer aporta un fragmento de una carta, escrita el 3 de noviembre de 1902 a Joan Maragall, en la que el rector de la universidad salmantina hace saber a su amigo que

[...] ando metido en una nueva novela, La tía, historia de una joven que rechazando novios se queda soltera para cuidar sobrinos, hijos de una hermana que se le muere. Vive con el cuñado, al que rechaza para marido, pues no quiere manchar con el débito conyugal el recinto en que respiran aire de castidad sus hijos. Satisfecho el instinto de maternidad, ¿por qué ha de perder su virginidad? Es Virgen madre. Conozco el caso.

Del artículo necrológico escrito por Unamuno al hilo de la muerte de Emilia Pardo Bazán, fechado el 27 de mayo de 1921, Mainer extrae asimismo que hubo una primera versión de la novela que complació a la escritora gallega, y que luego hubo otra (escrita probablemente entre 1917 y 1919) que terminó en la imprenta.

A la luz de estos datos, y sobre todo de una peripecia sin ninguna atadura temporal, podemos colegir que la historia de La tía Tula es rigurosamente coetánea a su prolongada gestación o, si se prefiere, que transcurre en ese presente suspendido de veinte años en los que su autor fue madurando pacientemente una idea original, surgida, al parecer, a raíz de un caso real de tulismo, del que nuestro filósofo trabó conocimiento en su juventud. Indefinición cronológica que tiene su corolario en la abstracción del locus de una trama sin asiento, ni asidero geográfico preciso ubicable genéricamente en la geografía mesetaria española, siquiera sea porque (ver capítulo 11) la única vez que los protagonistas abandonan su ciudad (posible- 
mente Salamanca, aunque vaya usted a saber) lo hacen para veranear en «un pueblecito costero que tuviese montaña, dominando al mar y por este dominada».

No queda ahí la cosa, puesto que en consonancia con las nivolas unamunianas el esquematismo contextual de la historia se reproduce en el diseño de los personajes, criaturas planas, monotemáticas y unidireccionales puestas en escena en tanto que caracteres-concepto, suerte de corporeización antropomorfa de ideas filosóficas sin trasfondo psicológico plausible desde una óptica realista.

Es imposible sopesar cabalmente el uso cinematográfico que ha deparado la novelística unamuniana sin advertir que sus señas de identidad obligan a su potencial adaptador a maniobrar prácticamente en el vacío. Quiere decirse que la esencialidad y esquematismo de los tres pilares narrativos -espacio, tiempo y perfil caracteriológico de los personajes-, parámetros reducidos a su mínima expresión conceptual, dejan casi todo por hacer, decidir o concretar. Esto nos permite conjeturar sobre la imposibilidad de adaptar (fielmente) a Unamuno, o da pie a señalar la circunstancia de que, abocándolas irremediablemente al peligro del exceso de ingerencia, sus nivolas se blindaron en buena medida ante posibles adaptaciones/manipulaciones ulteriores, sobre todo frente aquellas concebidas con arreglo a parámetros comerciales o a los gustos de una mayoría habituada a la dramaturgia canónica. De hecho, como hacen patente las referencias literarias del prólogo de La tía $T u l a^{7}$, su praxis novelística no solo marca distancias respecto a los principios dominantes en la novela realista decimonónica, sino que lo hace también respecto a los usos dramatúrgicos coetáneos del resto de los medios de expresión narrativos a los que mira con anacrónico desdén.

Desde su propio genérico, donde se especifica que la película está «inspirada» en la obra homónima de Miguel de Unamuno, la adaptación de $L a$ tía Tula, que Manuel Picazo dirigió en 1964, parece apercibida de todas estas decisivas cuestiones. Por de pronto, ese limbo ahistórico en el que se atisba a duras penas la España provinciana de principios de siglo trasmuta en los espacios reales de la Guadalajara ${ }^{8}$ de mediados de los años sesenta, con el peaje que ello se cobra en lo referido a los usos y costumbres de unos personajes a los que se les otorga ex novo una dimensión sociológica de la que

7 Amén de autoalusiones a Niebla y a Abel Sánchez, Unamuno se mira en Vida de Santa Teresa de Jesús, La vida es sueño de Calderón, Antígona de Sófocles y el Génesis.

${ }^{8}$ Guadalajara capital en el grueso del filme y la población alcarriana de Brihuega en la tórrida sección del pueblo. 
sus antecedentes literarios carecían por completo. La integración de Tula en una bullanguera cuadrilla de amigas con las que, en paralelo a las reuniones parroquiales, celebra etílicas despedidas de soltera, o las correrías venéreas que Ramiro emprende por los agrestes lupanares al aire libre del extrarradio de la ciudad, contrastan poderosamente con los monásticos personajes que Unamuno circunscribe a la claustrofóbica celda familiar. Por si fuera poco, en estos rituales sociales, como señala Juan Miguel Company (2003: 408409), se refractan los hábitos morales y religiosos del «estamento de los pequeños terratenientes castellanos que fueron predio electoral de Falange durante la República y una de las bases sociales del franquismo tras la victoria del golpe militar en $1939 »^{9}$, con lo que, para decirlo rápido, el sinóptico trazo diegético de Unamuno que se mira en los relatos míticos (Génesis, Antígona...), experimenta en manos de Picazo y sus colaboradores (junto a él firman el guión Luis Sánchez Enciso, Manuel López Yubero y José Miguel Hernández) un desplazamiento hacia el espacio genérico de un realismo de raigambre costumbrista.

Amén de encuadrar espacio-temporalmente la historia, esta maniobra de aclimatación de La tía Tula a los estándares dramáticos de corte realista apuesta por quedarse con el cañamazo del drama (el conflicto entre Tula y su cuñado viudo), prescindiendo de sus antecedentes (boda, maternidad triple y muerte de su hermana Rosa), así como de sinuoso desarrollo posterior (nuevo matrimonio de su cuñado Ramiro, nacimiento de dos nuevos sobrinos, muerte de la segunda esposa de Ramiro, de éste y de la propia Tula). Quizá se aprecie mejor la magnitud de la sangría expresada numéricamente: de los veinticinco capítulos de los que consta la nivola, el filme desarrolla grosso modo la acción contenida en los siete centrales, los que van del número 7 (el sexto describe la muerte de Rosa con cuyo velatorio echa a andar el filme) al número 14 (en el que una desvalida muchacha, que a no tardar será su esposa, es preñada por Ramiro).

Esta monumental purga deja fuera de foco un copioso número de personajes secundarios: de los cinco sobrinos de Tula (tres sanguíneos por parte de hermana, dos putativos hijos del segundo matrimonio de Ramiro) solo aparecen dos hijos de su hermana (Ramirín y Rosita, que pasa sintomáticamente a llamarse a Tulita); de los dos pretendientes externos de Tula (un amigo de Ramiro y Don Juan el médico) solo persiste, el primero aunque con

9 Sostiene Company (2003) que a este respecto es ejemplar la escena en la que Tula recauda lo estipulado a sus renteros a quienes termina por obsequiar los vestidos de su difunta hermana, al tiempo que amonesta a uno que no cumple con los plazos de pago. 
otro nombre (el Ricardo de la novela pasa a llamarse Emilio en el filme); el llorado tío Primitivo no consta ni a título de inventario... Pero sobre todo prescinde de lo que Mainer llama «copiosa acción de la biología»; a saber, los cinco partos (tres de su hermana, dos de su cuñada apócrifa) a los que asiste decisivamente Tula, al extremo de que, tras el nacimiento de su primer sobrino al que salva de la muerte segura, el médico le espeta: «Es usted comadrona de nacimiento», así como las cuatro muertes que vive in situ (la de su amado tío cura Primitivo, la de su hermana Rosa, la de su cuñado Ramiro y la de la frágil Manolita con la que este se casa en segundas nupcias), a las que habría que sumar la defunción de la protagonista que deja este mundo rodeada de sobrinos y en olor de santidad. Este tráfago de vida y muerte, nodal en Unamuno, ni siquiera es apuntado en el filme.

Sea como fuere, la alteración más decisiva emprendida por Picazo y sus colaboradores concierne al perfil narrativo de ese personaje axial que, afectado por «la fiebre de la maternidad virginal, de la virginidad maternal», encarna esencialmente la aleación de contrarios. La Tula unamuniana es, en esencia, negación taxativa, lo que, formulado en terminología narrativa, implica No Hacer, en este caso aquello que Dios y / o la Naturaleza esperan de ella, no cumplir, si se prefiere, la misión biológico-actancial inherente a la fémina («el oficio de una mujer es hacer hombres y mujeres, no vestirlos», espeta vehemente la propia Tula a su hermana Rosa cuando distraída en la costura desatiende esas «labores» cuasi zoológicas prioritarias en su género).

No obstante, hay que hacer notar que su rechazo a la maternidad biológica (su No Hacer) es efecto causado por su aversión a la suciedad, característica sin la que no es posible apreciar en sus justos términos al personaje unamuniano, toda vez que su acerba androfobia (su inquina hacia el colaborador o sujeto adyuvante necesario para la procreación y, por extensión, su numantina defensa del virgo) lo es, en puridad, de la polución intrínseca al coito.

Así las cosas, para Tula el varón resulta ser un avatar de esa mugre que abomina en todas sus manifestaciones: le da reparo el barro, el estiércol..., le repugna la sangre «sobre todo la negra y cuajada», huye despavorida al ver el vómito de su hermana moribunda, abre el balcón «para que se vaya el olor a hombre», asocia la regurgitación de un recién nacido con el semen, y muere tras una delirante filípica en la que atribuye propiedades sanadoras a esa porquería de la que ha huido toda su vida («Fango hay en el Purgatorio, fango ardiente, que quema y limpia..., fango que limpia, sí... En el Purgatorio les queman a los que no quisieron lavarse con fango, sí, con fango... Les que- 
man con estiércol ardiente..., les lavan con porquería... Es lo último que os digo, no tengáis miedo a la podredumbre... Rogad por mi y que la Virgen me perdone», cap. 23).

El filme asume grosso modo estos rasgos narrativos idiosincráticos de Tula, pero altera hasta extremos irreconocibles la cualidad modal de ese No Hacer. El filme respeta el enunciado de No Hacer del Sujeto Agente, pero desbarata la estilizada ecuación modal que lo sostiene en su versión literaria. La Tula unamuniana, que Debe Hacer (procrear) pero No Quiere (porque ensucia), padece un estruendoso conflicto interno («una brava galerna» en la acerada pluma unamuniana) que se deriva del hecho (en buena medida pecaminoso) de que su Deseo se imponga a la Ley; en tanto que la Tula cinematográfica, que a la postre Quiere (casarse) pero No Puede (porque Ramiro comete el «desliz» con su prima y ya va teniendo una edad), sufre una frustración no menos lacerante, pero en ningún caso de naturaleza moral. La escena ferroviaria con la que culmina el filme, donde vemos a Tula varada en la estación tras musitar para sí el nombre de ese Ramiro que acaba de irse con su mujer e hijos dejándola, en paralelo inequívoco con la Isabel de Calle Mayor (Juan Antonio Bardem, 1956), más sola que la una y abocada a «vestir santos», deja bien a las claras el cambio cualitativo que media respecto a la fémina unamuniana que se aferra a su castidad con delectación masoquista.

Pero si este vaciado moral del personaje central, a todas luces inducido por el deseo de conferir plausibilidad a una peripecia que se traslada a la España de los años sesenta, constituye el ápice de las modificaciones efectuadas sobre el material dramático de partida, la adaptación cinematográfica cuenta con una serie de decisiones y maniobras en las que trasluce cierto deseo de fidelidad no tanto a la letra de Unamuno, cuanto al espíritu de su nivola. Estamos pensando, por ejemplo, que los bravíos personajes que la actriz había encarnado hasta la fecha, en especial bajo la batuta de Juan de Orduña, convirtieron a la cabeza del cast, Aurora Bautista, en la encarnadura perfecta de esa «brava galerna» que bulle en el interior de Tula. Buena parte del acierto de este desaforado personaje unamuniano estriba en su opacidad, en el hecho de que su maremoto emocional atraviesa tímidamente la barrera de las apariencias coagulado en un ramillete de indicios sintomáticos tales como su mirada («esos ojazos tristes, de luto que se le meten a uno en el corazón» como afirma su tío sacerdote), la energía que emana de su organismo («Qué cuerpo, ¡Irradia fuego!», exclama don Juan, el médico), o su entusiasmo por la geometría («ciencia árida y fría al sentir de los más, encontraba en Gertrudis un no sabía qué de luminosidad y pureza») contrapuesta por su des- 
precio de la anatomía y la fisiología. Pues bien, Picazo hace suya esa técnica parabólica, consistente en reflejar los sentimientos de su impenetrable personaje a través de un variado catálogo de pantallas, y ensaya a traducir fílmicamente algunos de los síntomas y vestigios en los que su recóndito conflicto aflora en la novela. Veamos algunos ejemplos demostrativos.

Aunque severamente mermada, la aversión a la suciedad de Tula pervive en su trascripción cinematográfica en esa Aurora Bautista a la que vemos fregar la vajilla con celo, planchar la colada salpicándola con agua o limpiarse, restregándolas enérgicamente con agua y jabón, las manos después de que estas hayan entrado en contacto con el rostro de Ramiro cuando la solterona atiende a su cuñado postrado en la cama por un acceso de amigdalitis. El agua había servido a Unamuno para ejecutar una de las metáforas naturales que alumbran la personalidad de Tula: «Y era a la vez el espíritu de Rosa como un reflejo de el de su hermana, como el agua corriente al sol de que aquél era el manantial cerrado» (cap. 7). Mucho más tarde, los ojos de Manolita, el último de los vástagos apócrifos de Tula, que «Parecen dos estanques quietos entre verdura» (cap. 20) resultan ser como los de Tula. No solo el agua, la naturaleza sirve en su variada plenitud a Unamuno como espejo literario del fragor emocional de los personajes; por ejemplo, en su salida de veraneo leemos:

Gertrudis (Tula) estaba brizando la pasión de Ramiro para adormecérsela. No le miraba casi nunca entonces, miraba al mar; pero en él, en el mar, veía reflejada por misterioso modo la mirada del hombre. El mar purísimo les unía las miradas y las almas [...] El campo en vez de adormecer, no la pasión, el deseo de Ramiro, parecía como si se lo excitase más, y ella misma, Gertrudis, empezó a sentirse desasosegada. La vida se les ofrecía más al desnudo en aquellos campos, en el bosque, en los repliegues de la montaña [...] No, el campo no rendía una lección de pureza. Lo puro allí era hundir la mirada en el mar. Y aun el mar... la brisa marina les llegaba como un aguijón (cap. 11).

Aunque donde más evidente resulta el usufructo descriptivo, que Unamuno extrae de la naturaleza y de sus aguas, es en ese manso y húmedo crepúsculo que alude en filigrana a la muerte de Tula:

Le dio un desmayo. Al volver de él no coordinaba los pensamientos. Entró luego en una agonía dulce. Y se apagó como se apaga una tarde de otoño cuando las últimas razas del sol, filtradas por las nubes sangrientas, se derriten en las aguas serenas de un remanso del río en que se reflejan los álamos —-sanguíneo su follaje también-que velan en sus orillas. 
Picazo, como decimos, ejecuta cinematográficamente los mismos alambiques parabólicos. La dicotomía de caracteres aludida por Unamuno mediante metáforas acuáticas (Rosa-agua corriente $v s$. Tula-manantial cerrado) es resuelta por Picazo en términos espaciales, pero con sentido inverso, oponiendo ese cementerio al que acude Ramiro a visitar la tumba de Rosa (escena que deviene terrorífica dado que una joven sufre en las inmediaciones un ataque de histeria ante el panteón de su amado), al exuberante jardín del pueblo, paisaje edípico que desata la euforia de una Tula que rememora proustianamente su infancia feliz. Aunque la traducción sonora de las zozobras emocionales de los personajes elucida mejor que ninguna otra la capacidad que exhibe Picazo a la hora de adaptar las tácticas parabólicas de Unamuno a un medio de expresión audio-visual como el cinematográfico. Sirvan de ejemplo los compases que anteceden a esos dos lances sexuales que el filme añade sin autorización de una novela en la que no cabe semejante grado de explicitud carnal.

Tras deambular por un descampado, en el que se ejerce la prostitución, Ramiro no puede conciliar el sueño acuciado por el deseo. Le vemos inquieto agitase en la cama, pero son los sonidos que vienen del exterior de la casa los que elucidan su emergente turbación pulsional: una campanas advierten que estamos a las 4:15 de la madrugada, risas femeninas, ruido de motor y algarabía de juega rasgan el silencio nocturno hasta que vuelve la calma, ruido metálico del somier producido por sus movimientos en la cama, ladridos de perro y, para concluir esta magistral escena aural, las campanas señalan las cinco de la madrugada. A la mañana siguiente, Tula entra en la habitación, abre con urgencia y desagrado la ventana para orearla, comienza a ordenar la cama y, cuando descubre un delator desgarro en la sábana, Ramiro se abalanza sobre ella y la intenta violar.

Más tarde, en el tórrido pueblo, no sólo Ramiro es asaltado por el deseo: vemos a Tula en su habitación a través de un espejo que nos advierte del desdoble que padecerá su personalidad al son del correoso Chachachá que cubre lascivamente toda la escena. La solterona sale de su habitación, toca la puerta de su cuñado, comprueba que no está en su cama y se dirige a la cocina a beber un baso de agua con el que pretende, a todas luces, enfriar sus enfebrecidos ánimos. Allí aparece Ramiro, quien afirma no poder dormir; Tula se deja mirar por su cuñado y antes de dirigirse a su habitación le espeta «si te encontraras mal, me avisas», a lo que este responde con un frígido «Bueno». Cuando ella se ha ido, Ramiro apaga las luces y vuelve a la habitación de Juanita a la que, pese a su oposición, posee. 


\subsection{Abel Sánchez (Carlos Serrano de Osma, 1946)}

Si como acabamos de ver, Picazo recurre a la novela de Unamuno para extraer de ella básicamente unos cuantos personajes y situaciones que luego alterará notablemente al situarlos en un contexto distinto al original y al dotarles de una complejidad psicológica y una riqueza de matices que no poseían en la novela, Serrano de Osma, siguiendo casi al pie de la letra el texto de Unamuno, confecciona un filme en el que los personajes no son sometidos al habitual desarrollo psicológico, sino que van a servir, cada uno de ellos, para encarnar un concepto abstracto predeterminado, una idea esquemática que los marcará a fuego de principio a fin, sin posibilidad de cambio. La otra gran diferencia entre ambos filmes se establece en el ámbito de la contextualización. Como ya hemos señalado la adaptación de Picazo está movida por una clara voluntad de hablar de un tiempo y de un espacio determinados: la España de provincias de los años sesenta. Sin embargo, Serrano de Osma (puede que condicionado por la difícil situación política de la inmediata posguerra) tomará el camino contrario y tratará, según sus propias palabras, de «dar una impresión real a las concepciones de Unamuno, fuera del tiempo y el espacio» ${ }^{10}$. Abunda en esta idea ese letrero que, situado al principio de la película, nos advierte del carácter meramente aparencial de la época y el ambiente que reproducirán las imágenes que van a surgir a continuación ${ }^{11}$.

Abel Sánchez es, como reza el título completo de la película ${ }^{12}$, la historia de una pasión. Y por eso, en la novela, primero, y en la película, después, lo único que encontraremos será precisamente eso, el relato de la vida de un hombre dominada por una pasión: la envidia. En un ejercicio de máxima concreción se suprime cualquier atisbo de trama secundaria, se recurre a unos diálogos extremadamente despojados de cualquier retórica innecesaria ${ }^{13}$, se

${ }^{10}$ Citado en Aranzubia (2007: 86).

${ }^{11}$ Conviene recordar que en el texto de Unamuno (1988) se habla de la envidia y de la pulsión fratricida, primordialmente, de forma genérica, aunque también es cierto que en varias ocasiones se hace referencia explícita a eso que Unamuno llama en el prólogo a la tercera edición de Niebla, el más terrible tumor comunal de nuestra casta española. En la película, las alusiones directas a la envidia como lepra nacional española han sido suprimidas. A este respecto, es significativa la omisión de esta parte del diálogo que Joaquín Monegro pronuncia en su lecho de muerte: «¿Por qué nací en tierra de odios? En tierra en que el precepto parece ser: "Odia a tu prójimo como a ti mismo"».

12 Resulta curioso constatar cómo Serrano de Osma sustituye el título original de la novela, Abel Sánchez: Una historia de pasión, por otro muy similar que el propio Unamuno (1988) recomienda en el prólogo a la segunda edición: Abel Sánchez. Historia de una pasión.

${ }_{13}$ Conviene señalar que prácticamente todos los diálogos de la película provienen del original unamuniano y que de los treinta y siete capítulos en que está dividido este, nada más y nada menos que treinta y cuatro aparecen reflejados de una u otra manera en el filme. Significativamente, dos de los capítulos que no aparecen abordaban tramas secundarias y el otro recogía una reflexión sobre la ortodoxia 
estructura el filme sobre la base de pequeñas escenas unitarias que, como ya sucedía en la novela (construida a partir de breves y numerosos capítulos), confieren al relato fílmico un ritmo brusco y sincopado; se obvian las descripciones de escenarios (de ahí la práctica inexistencia de esas panorámicas que habitualmente sirven para presentar paisajes y decorados); y se procede al esquemático tallado de unos personajes monolíticos y sin fisuras que, en última instancia, serán reconocidos por una única cualidad. Porque, como ya se ha mencionado en estas páginas, los personajes de las nivolas de Unamuno son arquetipos que encarnan, cada uno de ellos, un concepto abstracto, una idea básica e inmutable. De tal forma que Joaquín Monegro, protagonista del filme (a pesar del título), solo tiene sentido dentro del relato como personificación de la envidia. Absolutamente todos y cada uno de sus actos (tal vez quepa hablar de una posible redención en el lecho de muerte) están movidos por el carburante que le proporciona su odio a Abel (Roberto Rey). Y por eso, cuando Abel muera, morirá también Joaquín. Porque el envidioso necesita del envidiado para existir, aunque también es cierto (y volveremos sobre esto más adelante) que la necesidad es recíproca.

Otro aspecto significativo con respecto a la caracterización de Joaquín en la película viene dado por su reiterada aparición confeccionando pajaritas. La afición a la papiroflexia del personaje (que, lógicamente, no estaba en el libro) funciona como una clara alusión al autor de la novela. Así pues, identificando a Joaquín con Unamuno, Serrano de Osma insiste, por un lado, en esa teoría defendida por casi todos los estudiosos de la obra del pensador vasco, según la cual Joaquín Monegro es en muchos sentidos el trasunto literario de Unamuno ${ }^{14}, \mathrm{y}$, por otro, demuestra un profundo conocimiento de la complejidad de una novela (de su espíritu, si se quiere), en la que la envidia de Joaquín es presentada como una pasión «trágica» superior a las demás pequeñas envidias. Hasta el punto de que Unamuno (1998: 82), en el prólogo a la segunda edición de la novela, considerará a su Joaquín «moralmente, superior a todos los Abeles». Y tal vez por eso, el Abel que nos presenta Serrano de Osma es un personaje ligeramente menos atractivo que el de Unamuno; como ponen de manifiesto la mediocre calidad de sus pinturas, su esporádica tendencia al sarcasmo y su activa rivalidad con Joaquín en pos del afecto de su nieto.

que Serrano, con buen criterio, habida cuenta de lo receloso que se mostraba el Régimen por aquel entonces con las cuestiones que afectaban a la religión, prefirió no recuperar para su película.

${ }^{14}$ En la novela Joaquín Monegro escribe una confesión donde plasma su yo más íntimo. En dicha confesión aparecen algunas de las ideas básicas del pensamiento de Unamuno, que se pueden rastrear a lo largo de toda su creación literaria. Por otra parte, Carlos Clavería (1980: 227-249) encuentra en la figura del hermano de Unamuno una, más que posible, fuente de inspiración para el personaje de Joaquín. 
Si Joaquín, como decíamos, encarna a la envidia, Abel hace lo propio con la frivolidad. Pero lo hace de una manera no tan contundente como Joaquín. Porque Abel es, sin lugar a dudas, el personaje más difuso del filme. Se nos presenta como un artista de éxito que lleva una vida disipada (no lo vemos, pero en la película se hace referencia a su conducta adúltera), tiene buenas intenciones y es simpático, pero demuestra un escaso apego por los valores de la familia. Antonia (Mercedes Mariño), la mujer de Joaquín, simboliza, en cambio, todo lo contrario. Ella es la esposa-madre ${ }^{15}$, defensora a ultranza de la institución familiar. Y, por último, nos encontramos con Helena: rotunda e inequívoca encarnación de la belleza.

La presentación de Helena ${ }^{16}$ constituye, sin lugar a dudas, uno de los momentos más logrados del filme y merece por ello una especial atención. En el final de la escena inmediatamente anterior Abel le expone a Joaquín su intención de utilizar a Helena, la prima de Joaquín, como modelo para un cuadro. Joaquín, que está enamorado de su prima, acepta no muy convencido. Lo siguiente que vemos es un plano de la mano de Abel dibujando el rostro de Helena sobre un lienzo. En el preciso instante en que Abel da forma a la boca del retrato escuchamos una voz (todavía sobre el plano del cuadro) que dice: «Oiga Abel, ¿puedo hablar?». Lógicamente quien habla es Helena, como descubriremos a continuación mediante un plano de Abel dibujando sobre el lienzo, con Helena al fondo (ocupando la parte central del encuadre). Así pues, al hacer coincidir en el mismo plano el momento en que Abel pinta la boca de Helena con la voz de esta, Serrano de Osma identifica, de manera contundente y precisa, a Helena con su representación, con su imagen. Porque en resumidas cuentas Helena no es otra cosa que apariencia. Esta idea va a ser reforzada por el plano siguiente, en el que vemos a Abel en la parte izquierda respondiendo a la pregunta de la modelo que aparece (es la primera vez que la vemos) compartiendo el resto del encuadre con su representación: «Sí, puede usted hablar y moverse; para mí es mejor porque así vive la fisonomía... Esto no es fotografía. y además...»; un corte brusco nos sitúa ante un plano frontal de Helena (deslumbrante), sentada en un sillón, sobre el que escuchamos el final de la respuesta de Abel: «... no la quiero hecha estatua».

15 Figura recurrente en la obra de Unamuno y, según parece, de procedencia también autobiográfica. El personaje estaría inspirado en la mujer de Unamuno, a la que este solía referirse con el sobrenombre de «Costumbre». En la novela Joaquín habla de Antonia en términos similares.

16 Según Carlos A. Longhurst, editor de Abel Sánchez para Cátedra, «Helena con H evoca a la semidiosa griega que provocó la guerra de Troya entre dos pueblos y el combate entre dos hombres, su esposo Menelao y su raptor Paris». Al igual que en La tía Tula la tragedia clásica vuelve a ser el modelo de referencia (Unamuno, 1998: 88). 
El resto de la secuencia (hasta ahora hemos dado cuenta únicamente de los tres planos iniciales) sirve para plantear el conflicto amoroso que a la postre será, si no el origen, sí al menos el detonante de la tragedia. Para ello, se recurre a una eficaz planificación que encuentra toda su fuerza expresiva en una inteligente gestión del fuera de campo (cuando Helena, desde el sillón, interpele a su primito éste se encontrará ya, significativamente, fuera de campo) y en la disposición de las figuras dentro del encuadre (un gran plano general del estudio con Helena en la esquina izquierda, Abel en el medio y Joaquín en la derecha, dándoles la espalda, expresa visualmente la enorme distancia que ya desde los primeros compases del filme separa a los dos primos).

Acabamos de comprobar de qué manera la película hace que cada uno de sus personajes se convierta en la encarnación de un concepto determinado, que, en el caso de la pareja protagonista, sirve para reproducir esa dicotomía esencial entre el envidioso y el envidiado que atraviesa todo el relato. Sin embargo, una lectura más atenta del texto fílmico revela algo que ya escondía la novela (estaríamos, pues, ante uno de esos mandatos implícitos de los que hablábamos antes) y que Serrano de Osma ha sabido insertar de manera sutil e inteligente en el devenir de su discurso. Nos estamos refiriendo a esa reciprocidad, a esa complementariedad, a esa dependencia absoluta que se establece entre los dos personajes, hasta convertirlos finalmente en las dos caras de una misma moneda. Porque Caín necesita de Abel tanto como a la recíproca. Y por eso en un momento determinado Joaquín afirmará que de no haber matado Caín a Abel, habría sido este el asesino de su hermano. Porque, en resumidas cuentas, de la misma manera que todos llevamos dentro un Abel (en esencia, un ser socializado) también albergamos en nuestro interior a un Caín (un ser dominado por instintos primarios) ${ }^{17}$.

Serrano de Osma recupera algunas de las alusiones a la complementariedad de los dos amigos que ya estaban presentes en la novela - en un momento determinado, Joaquín llama a Abel pintor científico, y Abel a Joaquín médico artista; uno de los invitados al homenaje asegura que el cuadro de Abel no sería nada sin el discurso de Joaquín - y añade otras, como la de ese plano imposible del rostro bifásico de Joaquín: mitad sonrisa, mitad desdén; o ese primerísimo primer plano de los ojos de Joaquín, con las voces de ambos superponiéndose en la banda de sonido; o esos dos planos subjetivos

${ }^{17}$ Es bien sabido que el propio Unamuno, como oportunamente se ha encargado de recordar González Egido (Unamuno, 2001: 47), se veía a sí mismo como la fusión de una larga serie de dicotomías: «agónico y contemplativo, racional y sentimental, creyente y ateo, filósofo y poeta, vasco y castellano, nómada y sedentario, en definitiva, como un hijo de la contradicción [...]». 
de los protagonistas mirando al Caín del cuadro y, por lo tanto, identificándose con él. Pero, sin lugar a dudas, el momento privilegiado a este respecto tiene lugar en esa secuencia en la que los dos amigos discuten sentados, uno frente a otro (Joaquín ocupa la parte izquierda del encuadre y Abel la derecha), el mito de Caín: Joaquín le cuenta a Abel una broma que se gasta a los niños cuando aprenden de memoria la Historia Sagrada y que les lleva a confundir a Caín con Abel; cuando termina, se levanta de la silla y va a sentarse en otra que está colocada a la derecha de Abel, de tal forma que, cuando la cámara los reencuadre, será ahora Abel quien ocupe la parte izquierda del plano y Joaquín la derecha. Este sutil cambio de posiciones dentro del encuadre ilustra visualmente esa idea fuerte que atraviesa todo el texto y lo colma de sentido: la indisoluble fusión de los dos amigos, esto es, su complementariedad.

\section{FINAL}

Al igual que los personajes de Unamuno, las relaciones entre cine y literatura están marcadas por la idea de reciprocidad. Como hemos intentado demostrar a lo largo de este artículo, urge, por un lado, superar la fatigosa e improductiva querella en torno a la fidelidad y, por otro, renunciar al no menos vano intento de encontrar fórmulas generales que regulen el tránsito entre formas de existencia textual tan similares (comparten la práctica totalidad de los problemas narrativos) y tan diversas (la escritura y la imagen como formas diferenciadas de expresión). Más interesante es pensar que el viaje entre literatura y cine es, o puede ser, de dos direcciones y que, como en el caso del célebre poema, lo más apasionante del mismo reside menos en los puntos de partida o llegada que en el trayecto mismo. Y este es, por definición, único e irrepetible.

\section{REFERENCIAS BIBLIOGRÁFICAS}

ARANZUBÍA, A. (2007). Carlos Serrano de Osma: historia de una obsesión. Madrid: Filmoteca Española.

BAZIN, A. (1966). ¿Qué es el cine? Madrid: Rialp.

CLAVERÍA, C. (1980). «Sobre el tema de Caín en la obra de Unamuno». En Miguel de Unamuno, A. Sánchez Barbudo (ed.), 227-249. Madrid: Taurus. 
COMPANY, J. M. (2003). «La tía Tula (Miguel Picazo, 1964). Un alma llena de cuerpo». En Los «Nuevos cines» en España. Ilusiones y desencantos en los sesenta, Carlos F. Heredero y José Enrique Monterde (eds.), 408-409. Valencia: Festival de Cine de Gijón e IVAC.

GÉNETTE, G. (1996). L'oeuvre de l'art. Inmanence et trascendence París: Seuil (Versión española de Carlos Manzano: La obra del arte. Inmanencia y trascendencia, Barcelona: Lumen, 1997).

GOODMAN, N. (1968). Languages of Art. Bobbs-Merril Company (versión española: Los lenguajes del arte. Aproximación a la teoría de los símbolos, Barcelona: Seix Barral, 1976; con traducción de Jem Cabanes).

JAKOBSON, R. (1959). «On Linguistic Aspects of Translation». En On Translation, Reuben A. Broker (ed.). Cambridge: Harvard University Press.

PASOLINI, P.P. (1966). «Le scénario comme structure tendant vers une autre structure». Cahiers du Cinéma 185, 76-83 (versión original: Empirismo Eretico, Milán: Garzanti, 1972).

ROBBE-GRILLET, A. (1957). La jalousie. París: Minuit (versión española de Juan Petit: La celosía, Barcelona: Seix-Barral, 1965).

STEINER, G. (1995). Después de Babel. Aspectos del lenguaje y la traducción. México: Fondo de Cultura Económica (versión original: After Babel: Aspects of Language and Traduction, Oxford University Press, 1992).

UNAMUNO, M. de (1988). Abel Sánchez [1917]. Madrid: Cátedra.

- (2001). Abel Sánchez [1917]. Madrid: Alianza Editorial.

- (2002). La tía Tula [1921]. Madrid: Alianza Editorial. 